\title{
Anti-diabetic mechanism of melania snail (Semisulcospira libertina) protamex hydrolysates
}

\author{
Sang-Eun Pyo, Jae-Suk Choi, Mi-Ryung Kim* \\ Major in Food Biotechnology, Division of Bioindustry, Silla University, Busan 46958, Korea
}

\section{다슬기 protamex 가수분해물(MPH)의 항당뇨 기작 연구}

\author{
표상은 · 최재석·김미령* \\ 신라대학교 바이오산업학부 식품공학전공
}

\begin{abstract}
Melania snail (Semisulcospira libertina) was traditionally used as the healthy food in Korea. It was generally known to improve liver function and heal a diabetes. The aim of this study was to elucidate the anti-diabetic mechanism of melanian snail hydrolysates treated with protamex (MPH) by investigating the inhibitory action on protein tyrosine phosphatase 1B (PTP1B), the improving effect on the insulin resistance in $\mathrm{C2C12}$ myoblast and the protective effect for pancreatic beta-cell (INS-1) under the glucose toxicity. The melania snail hydrolysates treated with protamex (MPH), which showed the highest degree of hydrolysis $(43 \%)$, and inhibited effectively PTP1B activity $\left(\mathrm{IC}_{50}=\mathbf{1 5 . 4 2 \pm 1 . 1}\right.$ $\mu \mathrm{g} / \mathrm{mL}$ ), of which inhibitory effect was higher than usolic acid, positive control $\left(\mathrm{IC}_{50}=16.65 \mu \mathrm{g} / \mathrm{mL}\right)$. MPH increased the glucose uptake in C2C12 myoblast treated with palmitic acid. In addition, MPH increased insulin mRNA expression level by over $160 \%$ with enhanced cell viability in INS-1 cell under the high glucose concentration $(30 \mathrm{mM})$. These results suggest that MHP may improve the diabetic symptom by the inhibiting the PTP1B activity, increasing the glucose uptake in muscle cell and protecting the pancreatic beta-cell from glucose toxicity.
\end{abstract}

Key words : melania snail hydrolysates, anti-diabetic mechanism, PTP1B inhibition activity, glucose uptake, insulin

\section{서 론}

최근 풍요로운 식생활과 생활환경변화로 인한 운동부족 등의 원인으로 다양한 만성 질환이 꾸준히 증가하고 있다 (1). 특히 당뇨병은 급성 및 만성 합병증뿐만 아니라 사망률 이 높아 전 세계 인류의 건강을 위협하고 있다(2). 세계보건 기구(WHO) 보고에 의하면, 2014년 현재 전 세계 성인 중 당뇨병 환자는 4 억 2 천 2 백만 명에 이르고 있으며, 이 중 120 만 명이 당뇨병으로 인해 목숨을 잃고 있다고 한다(3).

*Corresponding author. E-mail : haha7kmr@silla.ac.kr Phone : 82-51-999-5873, Fax : 82-51-999-5458

Received 30 October 2017; Revised 20 November 2017; Accepted 22 November 2017.

Copyright (c) The Korean Society of Food Preservation. All rights reserved.
당뇨병은 체내 혈당을 일정하게 유지하게 하는 대사활동이 정상적으로 이루어지지 않아 생기는 대사성 질환으로, 제 1 형(Type 1)과 제 2 형(Type 2) 당뇨병의 두 종류로 나눌 수 있다. 제 1 형 당뇨병은 전체 당뇨병의 약 $10 \%$ 를 차지하 고 있으며 췌장의 베타 세포의 문제로 인슐린을 제대로 생산하지 못하여 발생한다. 제 2형 당뇨병은 인슐린이 정상 적으로 분비됨에도 불구하고 간, 근육 및 지방조직 등의 말초 조직에서 인슐린의 활성 저하로 유도되는 인슐린 저항 성(insulin resistance)으로 인해 혈당 농도가 조절되지 않아 발생하며 당뇨병 환자의 대부분을 차지하고 있다(4).

당뇨 치료제는 크게 인슐린 제제, 설폰우레아계, 티아졸 리딘디온계, 비구아니드계, 미글리티나이드계, DPP-IV저 해제 등이 있으며(5), 장기 복용 시 저혈당 유발, 설사, 복부 팽만감, 체중증가, 젖산혈중, 심장독성, 간 독성 등의 다양 한 부작용을 일으킬 뿐만 아니라 결국에는 인슐린 분비 
기능을 하는 췌장의 베타세포를 비가역적으로 손상시켜 결국 인슐린을 주사해야 되는 상태가 된다. 그러나 이러한 인슐린 주사도 저혈당 유발 가능성이 매우 큰 문제점을 지니고 있다(6,7). 따라서 장기 복용 시에도 췌장 베타세포 보호 기능을 가지면서 저혈당 유발 없이 혈당 수치를 매우 효과적으로 낮춤과 동시에 인슐린 저항성을 해결할 수 있는 안전한 천연물 유래의 항당뇨 소재가 절실히 필요한 상황이 다. 지금까지 소개된 혈당 강하 활성을 가지는 천연물에는 인삼열매, 알로에, 담쟁이 덩굴, 버섯 및 그 관련 소재 등이 있다(8-11). 그러나 아직까지 당뇨환자의 증가율에 비해 천 연물 유래의 항당뇨 소재의 개발은 미약한 수준이다.

다슬기(Semisulcospira libertina)는 하천이나 호수 등지에 서 흔히 볼 수 있는 고동류로서 손쉽게 채취할 수 있고, 고단백질 건강식품으로 인식되어 있어 일찍이 우리나라에 서는 찜 또는 탕, 초무침 등으로 조리하여 식용되고 있다 (12). 동의보감 및 본초강목에서 기록된 바에 의하면 다슬기 는 예로부터 간염, 간경화, 지방간 등의 치료 및 개선에 이용되어 왔으며, 특히 소변불통, 소갈증(당뇨) 등의 약용으 로 널리 이용되어 왔다 $(13,14)$. 다슬기에 대한 최근의 국내 연구에는 간기능에 미치는 영향 $(14,15)$, 식품학적 성분 및 품질특성(16), 다슬기류 5 종의 항산화 활성(17), 국내산 7종 다슬기 추출물의 생리활성 특성 비교(13) 등이 보고되어 있다. 그러나 이러한 몇 가지 연구에서는 다슬기의 기초적 인 생리활성들만 보고되어 있을 뿐, 고문헌 등에서 언급되 고 있는 항당뇨(소갈증) 효능에 대한 과학적인 연구는 미비 한 상황이다. 앞서 본 연구팀은 고지방 식이로 당뇨를 유도 한 마우스에서 다슬기 가수분해물의 혈당강하, 간 및 신장 보호 등 항당뇨 효과를 보고한 바 있다(18). 본 연구에서는 다슬기 가수분해물이 나타내는 항당뇨 활성 기작을 확인하 기 위하여 췌장 베타세포 INS-1에서의 고농도 당독성에 대한 보호효과와 $\mathrm{C} 2 \mathrm{C} 12$ 근육세포에서의 포도당 흡수 증진 효과를 검증하고자 하였다.

\section{재료 및 방법}

\section{실험재료}

본 연구에 사용된 다슬기(Semisulcospira libertina) 살은 2015년도에 한국 내수면양식협회에서 제공받아 분쇄하여 사용하였다. 단백질 분해 효소는 상업적으로 널리 사용되 는 alcalase와 protamex(Novozyme Nordisk, Bagsvaerd, Denmark)의 총 2 종의 효소를 구입하여 사용하였다. Proteintyrosine phosphatase 1B(PTP1B, human, recombinant)는 BIOMOL International LP(Plymouth Meeting, PA, USA)사 에서 구입하였다.

\section{다슬기의 영양성분 분석}

다슬기의 일반성분 분석은 $\mathrm{AOAC}$ 법에 따라 수행하였다
(19). 수분 분석은 상압가열건조법, 조회분은 건식회화법, 조단백질은 Kjeldahl법 그리고 조지방은 soxhlet법으로 측 정하였다. 탄수화물은 100 에서 수분, 조단백질, 조지방, 회 분을 뺀 값으로 결정하였다.

\section{다슬기 효소가수분해물 $(\mathrm{MPH})$ 의 제조}

다슬기를 분쇄기로 균일하게 분쇄하고, 중량 대비 5 배의 $0.1 \mathrm{M}$ sodium phosphate buffer( $\mathrm{pH}$ 7.0)를 가한 후 $50^{\circ} \mathrm{C}$ 에서 10 분간 preincubation 시켰다. 효소 alcalase(A), protamex(P), alcalase+protamex $(\mathrm{A}+\mathrm{P})$ 를 각각 $2.4 \mathrm{AU} / \mathrm{kg}$ 가 되도록 첨가 하고 $50^{\circ} \mathrm{C}$ shaking incubator에서, $0,2,4,6,8,10$ 시간동안 각각 가수분해를 진행하였다. 이후 $100^{\circ} \mathrm{C}$ 에서 15 분간 처리 하여 가수분해 반응을 종결하였으며, 식힌 후, $4,500 \mathrm{rpm}$ 에 서 10 분간 원심분리한 상등액을 동결건조하여 실험에 사용 하였다.

\section{가수분해도 측정}

다슬기의 추출조건별 가수분해도는 각 가수분해물에 $20 \%$ trichloroacetic acid(TCA)를 동량 첨가하여 원심분리 $(2,370 \times g, 5 \mathrm{~min})$ 후 상층액을 취하여 Lowry assay(20)를 이용한 $10 \% \mathrm{TCA}$ 가용성 단백질량을 측정하여 다음 식으로 결정하였다.

$$
\text { 가수분해도 }(\%)=\frac{10 \% \mathrm{TCA} \text { 가용성 단백질량 }}{\text { 총 단백질량 }} \times 100
$$

\section{PTP1B 저해 활성}

다슬기 효소가수분해물 $6 \mu \mathrm{L}$, PTP1B $6 \mu \mathrm{L}$, 그리고 PTP1B buffer[50 mM citrate(pH 6.0), $0.1 \mathrm{M} \mathrm{NaCl}, 1 \mathrm{mM}$ EDTA, $1 \mathrm{mM}$ dithiothreitol(DTT)] $40 \mu \mathrm{L}$ 혼합물에, 기질인 $2 \mathrm{mM}$ $p$-nitrophenyl phosphate( $p$-NPP)를 $100 \mu \mathrm{L}$ 첨가하여, $35^{\circ} \mathrm{C}$ 에 서 30 분 간 반응한 후, $10 \mathrm{~N} \mathrm{NaOH} 50 \mu \mathrm{L}$ 를 첨가하여 반응을 종결시켰다. 생성된 $p$-nitrophenol의 농도는 microplate reader(Epoch, BioTek, Winooski, VT, USA)를 이용하여 405 $\mathrm{nm}$ 에서 흡광도를 측정하였으며, 음성 대조구는 $\mathrm{DW}$, 양성 대조구는 $16.7 \mu \mathrm{g} / \mathrm{mL}$ 의 ursolic acid(Sigma, USA)를 이용하 였다.

\section{C2C12 myoblast 배양 조건}

$\mathrm{C} 2 \mathrm{C} 12$ myoblast cell을 10\% fetal bovine serum(FBS, Hyclone, Logan, UT, USA), 100 units/mL penicillin 및 100 $\mathrm{\mu} / \mathrm{mL}$ streptomycin(Gibco, USA)이 첨가된 Dulbecco's modified Eagle's medium(DMEM, glucose $(4.5 \mathrm{~g} / \mathrm{L}$ ), $\mathrm{HyClone)}$ )에서 $37^{\circ} \mathrm{C}, 5 \% \mathrm{CO}_{2}$ 배양기에서 배양하였다. 세포 가 약 $70 \%$ 수준으로 배양되었을 때 $2 \%$ horse serum, 100 units $/ \mathrm{mL}$ penicillin 및 $100 \mu \mathrm{g} / \mathrm{mL}$ streptomycin이 첨가된 DMEM 분화배지로 교환하여 tube formation을 유도하기 
위해 4 일 동안 $37^{\circ} \mathrm{C}$ 에서 $5 \% \mathrm{CO}_{2}$ 조건으로 매일 새 배지로 교환하면서 배양하였다.

\section{$\mathrm{C} 2 \mathrm{C} 12$ myoblast에서의 MPH의 세포독성(MTS assy)} 세포독성은 3-(4,5-dimethylthiazol-2-yl)-5(3-carboxymethonyphenol) -2-(4-sulfophenyl)-2H-tetrazolium(MTS) assay를 사용하여 평가하였다. 96-well plate에 $1 \times 10^{4}$ cells/well의 $\mathrm{C} 2 \mathrm{C} 12$ myoblast를 분주한 후 $37^{\circ} \mathrm{C}, 5 \% \mathrm{CO}_{2}$ incubator에서 $24 \mathrm{~h}$ 배양하였다. $\mathrm{MPH}$ 를 농도별로 최종 $1,10,100,1,000 \mathrm{\mu g} / \mathrm{mL}$ 으로 처리하여 $24 \mathrm{~h}$ 동안 재배양하였다. 배양 후 각 well 당 $20 \mu \mathrm{L}$ 의 MTS solution(CellTiter $96^{\circledR} \mathrm{AQueous}$ One Solution, G3850, Promega, Madison, WI, USA)을 첨가 후 $\mathrm{CO}_{2}$ incubator에서 $1 \mathrm{~h}$ 반응 뒤 Microplate Reader(Multiskan $\mathrm{GO}$, Thermo Scientific, Finland)를 이용하여 $490 \mathrm{~nm}$ 에서 측정하였다.

\section{BSA-Conjugated Palmitate 제조}

인슐린 저항성을 유도하기 위해 BSA-conjugated palmitate (PA)를 제조하였다. Free fatty acid로는 palmitate(Sigma Co.)를 사용하였다. Palmitate를 $70^{\circ} \mathrm{C} 0.1 \mathrm{M} \mathrm{NaOH}$ 에 용해시 킨 다음, $55^{\circ} \mathrm{C}$ 에서 $10 \% \mathrm{BSA}$ (FFA-free BSA, Sigma Co.)과 10 분간 반응시켜 복합체를 형성시키고, 최종 농도 $5 \mathrm{mM}$ 로 조정하여 냉동 보관하고, 실험에 사용하기 1 일 전에 희석하 여 사용하였다.

\section{C2C12 myoblast에서 포도당 흡수(glucose uptake)} 측정

인슐린 저항성이 유도된 환경에서 다슬기 가수분해물에 의한 근육세포 $\mathrm{C} 2 \mathrm{C} 12$ myoblast의 glucose 흡수에 미치는 영향을 확인하고자, 세포 내로 유입되는 포도당 흡수량을 측정하였다. 96-well plate에 $\mathrm{C} 2 \mathrm{C} 12$ myoblast를 $5 \times 10^{3}$ cells/well의 농도로 분주하고, 4 일간 분화배지로 분화유도 후 BSA-conjugated palmitate(1 mM PA; sigma)를 16시간 동안 처리하여 인슐린 저항성을 유도하였고, serum free $\mathrm{DMEM}$ 에서 2시간 동안 배양하였다. 이후 다슬기 가수분해 물을 농도별 $(10,100,1,000 \mathrm{\mu g} / \mathrm{mL})$ 로 3시간 동안 처리한 다음, $100 \mathrm{nM}$ insulin을 10 분 동안 처리하였다. 마지막으로 $50 \mu \mathrm{M}$ fluorescent 2-N-(7-nitrobenz-2-oxa 1,3-diazol-4yl) amino-2-deoxy-D-glucose(2-NBDG; Invitrogen, USA)를 첨 가하여 15 분 동안 uptake를 유도하고, 상등액을 96-well plate에 옮긴 후 형광 분석기를 통해 측정하였다. 형광강도 는 excitation $485 \mathrm{~nm}$, emission $525 \mathrm{~nm}$ 하에서 측정하였다.

\section{PTP1B의 mRNA 발현량 측정}

PTP1B mRNA의 발현량을 C2C12 myoblast에서 RT-PCR 을 이용하여 평가하였다. 4 일간 분화된 세포에서 BSAconjugated PA를 16 시간 동안 처리한 후 $\mathrm{MPH}$ 를 농도별(10,
$100,1,000 \mu \mathrm{g} / \mathrm{mL}$ ) 또는 $100 \mathrm{nM}$ insulin으로 처리하여 3시간 동안 배양하였다. 배양 후 total RNA extraction kit(Doctor Protein, Seoul, Korea)를 이용하여 tRNA를 분리하였고, ImProm-ПTM Reverse Transcription System(Promega, $\mathrm{USA}$ )을 이용하여 cDNA를 합성하였다. PTP1B의 primer 서열은 5'-CCT ACC TGG CTG TCA TCG-3'(F), 5'-CCA CCA TCC GTC TCC TAA C-3'(R)을 사용하였고, $\beta$-actin은 5'-TGA CCG AGC GTG GCT ACA GC-3'(F), 5'-ACC GCR CAT TGC CGA TAG TG-3'(R)를 사용하였다. Dr. Taq-HOT Master Mix 2X with Dye(Doctor Protein) $10 \mu \mathrm{L}$, template cDNA $<500 \mathrm{ng}, 10 \mathrm{pM}$ primer를 이용하여 PCR을 실행하였 으며, $95^{\circ} \mathrm{C}$ 에서 5 분 preincubation하고, $95^{\circ} \mathrm{C}, 45$ 초, $57^{\circ} \mathrm{C}$, 1 분 30 초, $72^{\circ} \mathrm{C}, 45$ 초의 조건으로 30 cycle 반응, $72^{\circ} \mathrm{C}, 5$ 분으로 반응을 종료하였다. RT-PCR 산물은 $2 \%$ agarose gel에서 전기 영동하여 측정하였으며, mRNA 발현 수준을 비교하기 위해 $\beta$-actin과의 상대적인 비율을 확인하였다.

\section{췌장베타세포 INS-1 세포배양 조건}

췌장 베타세포주인 INS-1 cell은 10\% fetal bovin serum(FBS), 100 units $/ \mathrm{mL}$ Penicillin 및 $100 \mu \mathrm{g} / \mathrm{mL}$ streptomycin(Gibco), $50 \mathrm{mM}$ 2-mercaptoethanol이 첨가된 RPMI 1640 medium(Welgene, Gyeongsan, Korea)에서 $37^{\circ} \mathrm{C}$, $5 \% \mathrm{CO}_{2}$ 조건으로 배양하였으며 표준 농도 포도당 $(\mathrm{CG}$, control glucose)은 $11.1 \mathrm{mM}$ 로, 고농도 포도당 $(\mathrm{HG}$, high glucose)은 $30 \mathrm{mM}$ 로 하였다.

\section{췌장베타세포 INS-1 세포독성 평가(MTS assay)}

고농도 포도당의 세포에 대한 독성을 확인하기 위하여, INS-1 세포를 96-well plat에 well당 $6 \times 10^{3}$ cells을 분주하고 표준 농도 포도당 $(\mathrm{CG})$ 의 배지에서 24시간 배양한 후 각각 표준농도(CG)와 고농도 포도당(HG) 배지에서 $0,24,48$, 72,96 시간 배양하였다. 또한 다슬기 효소가수분해물이 고 농도 포도당에 의한 세포독성에 미치는 영향을 알아보기 위해, CG 배지에서 24시간 배양한 후 HG 배지를 처리하여 72 시간 배양하고, 다슬기 가수분해물을 농도별 $(1,10,100$, $1,000 \mu \mathrm{g} / \mathrm{mL}$ )로 24시간 동안 처리하여 총 96시간을 배양하 였다. 배양 후 $20 \mu \mathrm{L}$ 의 MTS solution을 첨가하여 1 시간 반응 후, Microplate Reader(Epoch, BioTek, USA)를 이용하 여 $490 \mathrm{~nm}$ 흡광도에서 측정하였다.

\section{인슐린 mRNA 발현량 비교}

고농도 포도당 노출시간에 따른 인슐린의 mRNA 발현량 차이를 측정하기 위하여 INS-1 세포를 6-well plate에 well 당 $1.2 \times 10^{5}$ cells이 되도록 분주하고 $\mathrm{CG}$ 배지에서 24 시간 배양한 후 $\mathrm{HG}$ 배지를 처리한 다음 $0,24,48,72,96$ 시간 배양하였다. 또한 다슬기 가수분해물이 고농도 포도당 독 성 하에서 인슐린 발현에 미치는 영향을 확인하기 위해, 
$\mathrm{CG}$ 배지에서 24 시간 배양 후 $\mathrm{HG}$ 배지를 처리하여 72 시간 배양하고, 다슬기 가수분해물을 농도별 $(1,10,100,1,000$ $\mu \mathrm{g} / \mathrm{mL}$ )로 처리하여 24시간 동안 처리하여 총 96시간을 배 양하였다.

배양 후 Total RNA extraction kit(DOCTOR PROTEIN, Korea)를 이용하여 tRNA를 분리하였고, ImProm- $\Pi^{\mathrm{TM}}$ Reverse Transcription System(Promega, USA)을 이용하여 cDNA를 합성하였다. 인슐린의 primer는 5'-CTA CAA TCA TAG ACC ATC AG-3'(F), 5'-TCC AGT TGT GGC ACT TGC-3'(R)를 사용하였으며, GAPDH는 5'-ACC ACA GTC CAT GCC ATC AC-3'(F), 5'-TCC ACC ACC CTG TTG CTG TA-3'(R)를 각각 사용하였다. $\mathrm{PCR}$ 반응은 $94^{\circ} \mathrm{C}, 5$ 분 Preincubation 후, $94^{\circ} \mathrm{C}, 30$ 초, $46^{\circ} \mathrm{C}, 30$ 초, $72^{\circ} \mathrm{C}, 30$ 초의 순서 로 30 cycle 반응 후, $72^{\circ} \mathrm{C}, 5$ 분으로 반응을 종결하였다. 인슐린의 mRNA 발현량은 GAPDH 발현량의 상대적인 비 율로 표시하였다.

\section{통계처리}

실험결과는 SPSS 9.0(SPSS Inc., Chicago, IL, USA)프로 그램을 이용하여 실시하였다. 평균 $\pm \mathrm{SD}$ 로 표시하였고 각 샘플간의 통계적 유의성은 INS-1에서의 고농도 당에서의 세포수와 인슐린발현에 대한 결과는 t-test를 실시하였으며, 그 외 다 군간의 유의성은 one-way ANOVA를 실시하였고, 다 군간의 차이는 $\mathrm{p}<0.05$ 수준에서 Duncan's multiple test로 검증하였다.

\section{결과 및 고찰}

\section{일반성분 분석}

다슬기의 일반성분 분석결과를 Table 1에 나타내었다. 수분 $78.6 \%$, 총당 $17.2 \%$, 조단백 $12 \%$, 조지방 $1.3 \%$ 및 조회 분 $3.9 \%$ 를 나타났으며, 열량이 $76.1 \mathrm{kcal}$, 콜레스테롤 70.9 $\mathrm{mg} / 100 \mathrm{~g}$, 나트륨 $79.1 \mathrm{mg} / 100 \mathrm{~g}$ 의 함량을 나타내었다. 건조

Table 1. Proximate composition of melania snail (Semisulcospira libertina)

\begin{tabular}{ccc}
\hline Components & $\begin{array}{c}\text { Composition } \\
(\%, \text { wet basis })\end{array}$ & $\begin{array}{c}\text { Composition } \\
\text { (\%, dry basis) }\end{array}$ \\
\hline Moisture (\%) & 78.6 & \\
Carbohydrate (\%) & 17.2 & 19.2 \\
Crude Protein (\%) & 12 & 56 \\
Crude Fat (\%) & 1.3 & 6 \\
Trans fat (\%) & 0 & \\
Cholesterol (mg/100 g) & 70.9 & \\
Ash $(\%)$ & 3.97 & 18.7 \\
Sodium $(\mathrm{mg} / 100 \mathrm{~g})$ & 79.1 & \\
\hline
\end{tabular}

중량으로 환산하면 조단백 $56 \%$, 조지방 $6 \%$, 총당 $19.2 \%$, 조회분 $18.7 \%$ 등으로 나타났다.

$\mathrm{Kim}$ 등의 연구(11)에서는 다슬기 건조중량으로 조단백 질 $60.74 \%$, 조지방 $7.1 \%$, 회분 $14.3 \%$ 이며, 탈지우유보다 높은 무기질의 함량을 함유하고 있어 $\mathrm{Ca}, \mathrm{Cu}, \mathrm{Fe}$ 급원의 하나로 영양학적 가치가 있다고 보고하였다. Shim 등(21)은 곳체 다슬기의 분석 결과, 수분 $80.7 \%$, 지방 $1.6 \%$, 단백질 $10.6 \%$, 회분 $2.9 \%$ 이라고 보고하였으며, $\mathrm{Lim}$ 등의 보고(16) 에서도 한국산 7종 다슬기의 수분은 $71-81 \%$, 조회분은 $1.9-6.4 \%$, 조지방은 0.4-1.6\%, 단백질은 $11.6-16.9 \%$ 의 함량 범위를 나타내어 본 연구 결과와 비슷한 결과를 나타내었 다.

\section{가수분해 시간에 따른 가수분해도 비교}

단백질은 20 여 가지의 아미노산의 조합으로 구성되어 있으며, 각각 그 기능과 특성이 다르다. 따라서 산이나 알칼 리 혹은 효소 처리에 의해 다양한 조성의 펩타이드로 구성 된 가수분해물을 제조할 수 있으며, 이러한 가수분해물은 원 단백질에 비해 더욱 다양한 기능성을 나타내고 있다. 그러나 산이나 알카리에 의한 화학적 처리는 유해물질의 생성과 필수아미노산의 손실 등의 문제점이 야기되고 있으 므로, 효소에 의한 부분 가수분해를 통해 새로운 기능성을 발견하고 향상시키려는 연구가 많이 시도되고 있다 $(22,23)$.

본 연구에서도 다슬기 생물학적 기능성을 높이기 위해 효소 가수분해를 실시하였으며, 그 가수분해 정도를 Fig. 1에 나타내었다. alcalase, protamex, alcalase+protamex의 3 종류 조건에 의한 다슬기 가수분해도는 거의 비슷한 패턴으 로 시간에 따라 증가하였다. 약 4시간까지 급격한 증가 이후 10 시간 까지 계속적인 증가양상을 보였다. 이 중 protamex 에 의한 가수분해도가 가장 높았으며, 10 시간 가수분해 후 약 $43 \%$ 의 가수분해도를 나타내었다.

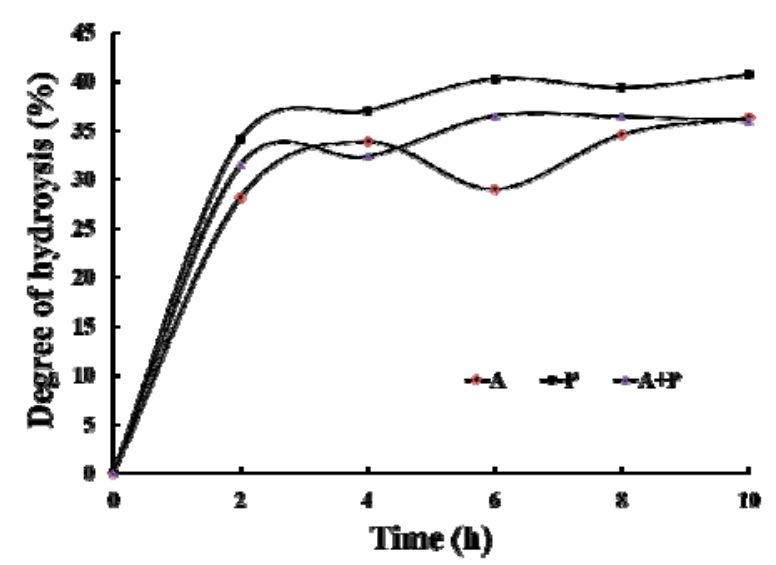

Fig. 1. Degree of hydrolysis of melania snail hydrolysates treated with three types of enzyme ( $A$, alcalase; $P$, protamex; $A+P$, alcalase+protamex) at different hydrolysis times. 


\section{PTP1B inhibition 활성 평가}

현재까지의 항당뇨 소재에 대한 연구는 주로 $a$ -glucosidase와 a-amylase 효소활성 억제, AMP-activated protein kinase(AMPK) 활성화, peroxisome proliferatoractivated receptor gamma(PPAR- $\mathrm{\gamma}$ )수용체 활성화, glucagonlike peptide-1(GLP-1) agonist 등에 초점을 맞추어 개발되었 지만, 위장장애, 간독성, 구토, 설사 및 복부팽만감 등의 부작용이 보고되고 있어 사용이 제한되고 있다(24). 최근에 는 protein-tyrosine phosphatase $1 \mathrm{~B}(\mathrm{PTP} 1 \mathrm{~B})$ 저해를 target으 로 한 연구가 진행되고 있다(25).

식후 섭취된 탄수화물은 a-glucosidase와 같은 탄수화물 분해효소에 의해 분해되어 혈당으로 흡수되고, 혈액이 고 농도 포도당 상태가 되면, 췌장의 베타세포는 인슐린을 분 비하게 된다. 분비된 인슐린은 인슐린 반응 조직인 근육, 지방세포, 간 등으로 이동하여 간에서는 포도당 합성을 저 해시키고, 근육 및 지방세포에서는 포도당 흡수를 촉진하 여 혈중 포도당 농도를 조절하는 역할을 수행하고 있다. 인슐린 반응 조직에서의 포도당 흡수기작은 인슐린 신호전 달기작으로 설명될 수 있다. 췌장에서 분비된 insulin이 인 슐린 수용체(insulin receptor, IR)와 결합하면 인슐린 신호전 달기작을 활성화되고, 이어서 인슐린 수용체 기질 1(insulin receptor substrates-1, IRS-1)의 타이로신 잔기의 인산화가 진행된다. 인산화된 IRS-1은 Phosphoinositide 3-kinase(PI3K) 와 반응하여 $\mathrm{PI} 3 \mathrm{~K}$ 의 활성을 유도하고 Phosphatidylinositol 3,4,5-triphosphate $\left(\mathrm{PIP}_{3}\right)$ 를 생성한다. 이어서 $\mathrm{PIP} 3$ 는 Phosphoinositide-dependent kinase 1(PDK1) 등의 protein kinases들을 활성화시키고. 이들 kinase들이 일련의 인산화 를 진행하면서 Akt를 활성화시킨다. 활성화된 $\mathrm{Akt}$ 는 glucose transporter 4(GLUT4)를 증가시키고 세포막 쪽으로 GLUT4 전이를 유도한다(GLUT4 translocation). 포도당 수 용체인 GLUT4는 혈중 포도당을 세포내로 흡수(glucose uptake)하여 혈중 포도당 농도를 조절하게 한다(26-29). PTP1B는 이러한 인슐린 신호전달기작에서 IR 및 IRS-1의 타이로신 잔기의 인산화반응을 방해하여 인슐린의 신호전 달 기전을 방해하고, 궁극적으로 제 2형 당뇨병을 유발시키 는 효소로 알려져 있다(30-32). PTP1B 유전자가 제거된 PTP1B 넉아웃(knock-out) 동물모델 실험에서, 근육세포나 간세포들이 인슐린에 민감하게 반응하며 2형 당뇨병이 유 발되지 않았다는 보고가 있었으며(33), 바나듐염(vanadium salts)과 같은 PTP1B 저해제들이 항당뇨 효과를 보이는 결 과도 보고된 바 있다(34).

본 연구에서는 PTP1B 저해를 타겟으로 하여 각 효소 가수분해물 $(1,000 \mu \mathrm{g} / \mathrm{mL})$ 의 가수분해 시간에 따른 PTP1B 억제 활성을 비교하였다(Fig. 2). 가수분해 2시간 이내에 모든 효소가수분해물의 PTP1B 저해활성이 급격히 증가하 였으며, 이후 10 시간까지 완만히 증가하여 약 $100 \%$ 의 저해 활성을 나타내었다. 최종 10 시간 후 각 가수분해물의
$\mathrm{PTP1B}$ 저해 활성을 $\mathrm{IC}_{50}$ 값으로 비교한 결과를 Table 2에 나타내었다. 양성대조군으로는 이미 PTP1B 저해제로 알려 져 있는 ursolic acid를 사용하였다. Protamex를 이용한 다슬 기 가수분해물 $(\mathrm{MPH})$ 의 경우, $\mathrm{IC}_{50}$ 값이 $15.42 \pm 1.1 \mu \mathrm{g} / \mathrm{mL}$ 을 나타내어 양성대조군 ursolic acid의 $16.7 \mathrm{\mu g} / \mathrm{mL}$ 보다 높은 정도의 저해활성을 나타내어 매우 높은 PTP1B 저해제로서 의 가능성을 보였다. 이후 $\mathrm{MPH}$ 를 이용하여 세포에서의 항당뇨 활성을 확인하였다.

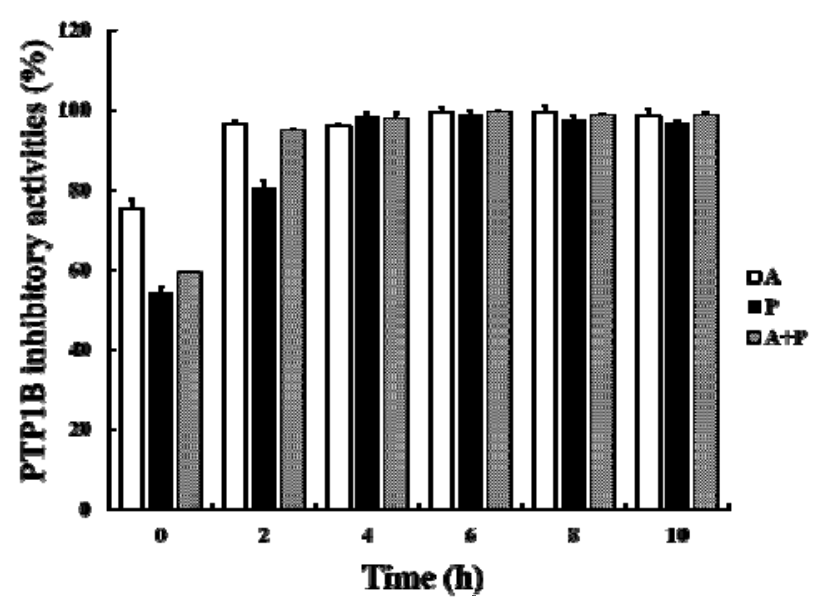

Fig. 2. PTP1B inhibitory activities of the melania snail hydrolysates $(1,000 \mu \mathrm{g} / \mathrm{mL})$ treated with three types of enzyme (A, alcalase; $P$, protamex; $A+P$, alcalase+protamex) at different hydrolysis times. Data are representative of three independent experiments as mean \pm SE.

Table 2. IC $_{50}$ value on PTP1B inhibition activity of melania snail hydrolysates treated by several enzymes

\begin{tabular}{ccc}
\hline \multicolumn{2}{c}{ Sample } & $\mathrm{IC}_{50}(\mu \mathrm{g} / \mathrm{mL})$ \\
\hline Ursolic acid (positive control) & 16.7 \\
& $\mathrm{~A}^{1)}$ & $36.32 \pm 1.2^{2)}$ \\
Melania snail & $\mathrm{P}$ & $15.42 \pm 1.1$ \\
hydrolysates & $\mathrm{A}+\mathrm{P}$ & $50.45 \pm 1.1$ \\
\hline
\end{tabular}

${ }^{1)} \mathrm{A}$, alcalase; $\mathrm{P}$, protamex: $\mathrm{A}+\mathrm{P}$, alcalase+protamex.

${ }^{2)}$ Date are representative of three independent experiments as mean $\pm \mathrm{SE}$.

$\mathrm{C} 2 \mathrm{C} 12$ myoblast에서 $\mathrm{MPH}$ 의 포도당 흡수(glucose uptake) 증진효과

인슐린은 포도당과 지방의 대사를 조절하는 주요 호르몬 이다. 식후 분비된 인슐린은 인슐린 반응 조직인 근육, 지방 세포, 간 등으로 이동하여 간에서는 포도당 합성을 저해시 키고, 근육 및 지방세포에서는 포도당 흡수를 촉진하여 혈 중 포도당 농도를 조절하는 역할을 수행하고 있다(35). 그러 나 고혈당에서 정상적으로 인슐린이 분비되어도 인슐린 반응 세포들이 이러한 인슐린을 이용할 수 없거나, 인슐린 과 IR이 결합하여도 다음 단계의 인슐린 신호전달과정이 진행되지 않아 혈당 조절작용이 저하된 상태가 나타나게 되면, 이러한 상태를 인슐린 저항성이라고 한다. 인슐린 
저항성의 원인에 대해서 여러 가지 기전이 보고되고 있으 며, 이중 특히 혈중에서 증가된 과량의 유리지방산(free fatty acid)은 포도당 운반을 억제하여 인슐린 활성을 저하시 켜 인슐린 저항성을 유도하는 것으로 알려져 있다 $(33,36,37)$.

$\mathrm{MPH}$ 가 인슐린 저항성을 개선하여, 포도당 흡수를 증가 시키는지를 확인하기 위해, 인슐린 반응세포인 mouse 유래 근육세포 $\mathrm{C} 2 \mathrm{C} 12$ myoblast에 BSA-conjugated palmitate(PA) 를 18 시간동안 처리하고 $\mathrm{MPH}$ 를 농도별로 3 시간 처리하여 포도당 흡수량을 측정하였다. 우선 근육세포 $\mathrm{C} 2 \mathrm{C} 12$ myoblast에 대한 다슬기 가수분해물(MPH)의 세포독성을 확인하기 위하여, $1,10,100,1,000 \mu \mathrm{g} / \mathrm{mL}$ 의 $\mathrm{MPH}$ 처리에 의한 cell viability를 MTS assay를 이용하여 측정하였다. 그 결과, 모든 농도에서 어떠한 세포독성도 보이지 않았으 며, 오히려 $\mathrm{MPH}$ 에 의한 세포성장이 농도 의존적으로 증가 하는 것으로 나타났다(Fig. 3). 이는 다슬기 가수분해물이 단백질 가수분해물임을 감안할 때 영양성분으로 작용되었 을 것으로 사료된다.

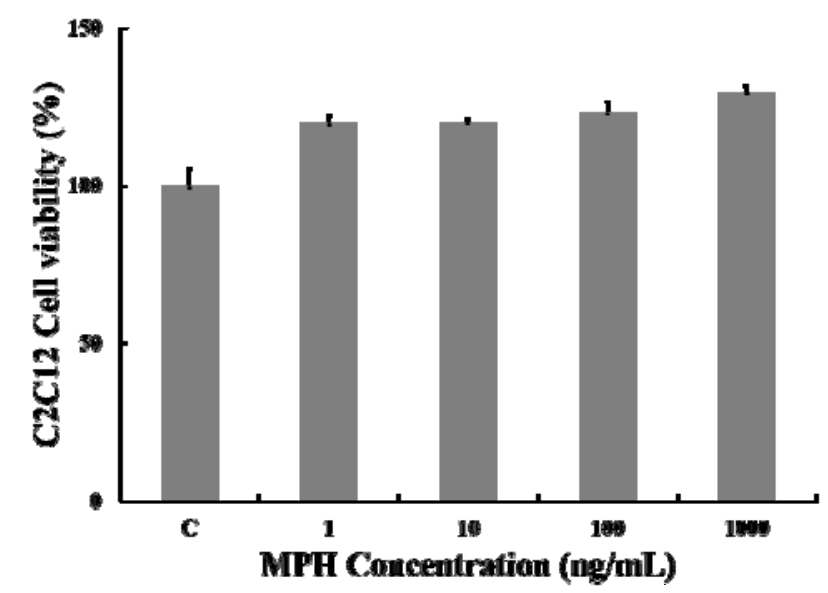

Fig. 3. Effects of the melania snail hydrolysates treated with protamex (MPH) on the cell viability of $\mathrm{C} 2 \mathrm{C} 12$ myoblast.

The $\mathrm{C} 2 \mathrm{C} 12$ myoblast were treated with the indicated concentration of MPH for 24 h. The cell viability was assessed by MTS assay. Data are representative of three independent experiments as mean $\pm \mathrm{SE}$.

인슐린 저항상태인 인슐린 활성저하 환경을 확인하기 위하여, $2 \%$ horse serum 첨가에 의해 유도된 분화 4 일차의 $\mathrm{C} 2 \mathrm{C} 12$ myoblast에 $100 \mathrm{nM}$ 인슐린 단독처리와 $1 \mathrm{mM} \mathrm{PA}$ 처리 후 인슐린을 각각 처리하였다. 분화된 $\mathrm{C} 2 \mathrm{C} 12$ myoblast 에서 인슐린 처리에 의한 포도당 흡수가 증가하였으며, 이 는 인슐린에 의한 포도당 흡수능의 일반적인 현상이다. 또 한 PA 처리 후 인슐린 처리에 의해 다시 포도당 흡수는 약 $32 \%$ 수준으로 감소하여 인슐린 활성저하 환경이 유도되 었음을 확인할 수 있었다. 다음으로 인슐린 활성 저하 환경 에서 $\mathrm{MPH}$ 의 농도별 $(10,100,1,000 \mu \mathrm{g} / \mathrm{mL})$ 처리에 의해 인슐린 단독 처리군에 비해 포도당 흡수가 약 $149 \%, 191 \%$,
$199 \%$ 로 농도 의존적으로 증가하였으며, 특히 $100,1,000$ $\mu \mathrm{g} / \mathrm{mL}$ 에서 PA 처리 후 인슐린 처리군에 비해 약 6 배 이상의 포도당 흡수가 증가하였다(Fig. 4). 이상의 결과에서 다슬기 가수분해물 MPH는 PA, 지방산 독성에 의해 유도된 인슐린 저항성 환경에서 근육세포의 인슐린 민감성을 회복시켜 glucose uptake를 증가시키고 인슐린 저항성을 개선하는 것으로 판단되었다.

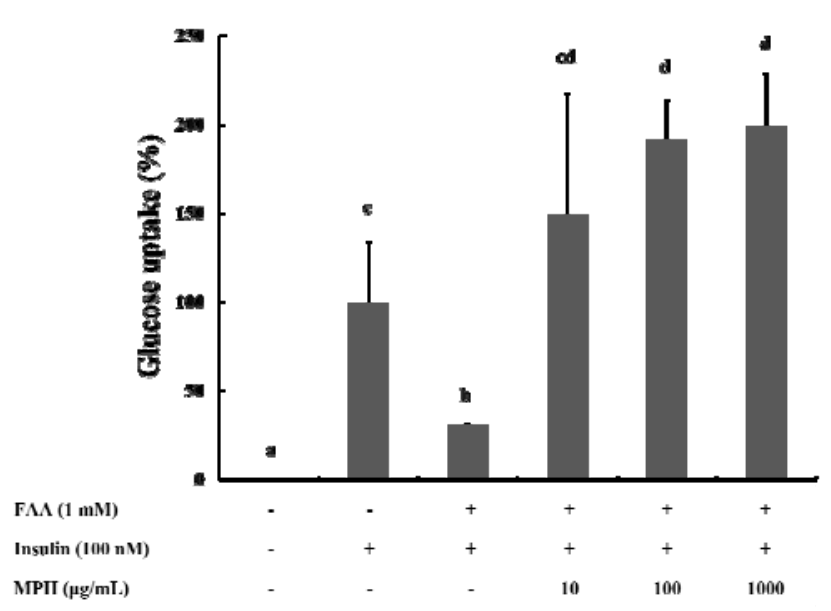

Fig. 4. Effect of melania snail hydrolysates treated with protamex (MPH) on glucose uptake in C2C12 myoblast.

C2C12 cell were treated with palmitic acid $(1 \mathrm{mM})$ for $16 \mathrm{~h}$. Before harvesting, the cells were incubated in the serum free DMEM for $2 \mathrm{~h}$ and then treated with samples $(10-1,000 \mu \mathrm{g} / \mathrm{mL})$ for $3 \mathrm{~h}$. Data are representative of three independent experiments as mean $\pm \mathrm{SE}$. a, b, c, and $\mathrm{d}$ mean they are significantly different groups at $\mathrm{p}=0.05$.

\section{$\mathrm{MPH}$ 의 PTP1B mRNA 발현 억제 효과}

비만, 당뇨, 이상지질혈증, 고혈압 환자에서 혈중 유리지 방산의 농도가 증가되면 protein kinase $\mathrm{C}$ isoforms(PKCs), nuclear factor- $\mathrm{KB}$ kinase(NF-K $\beta)$, C-Jun N-terminal kinase (JNK), p38 MAP kinase등과 같은 다양한 serine/threonine kinase 활성화되며, 특히 PTP1B의 활성을 유도하여, IRS-1 의 tyrosine 잔기의 인산화를 저해시키고, serine 잔기의 인 산화를 활성화하여, 체내 인슐린 신호 전달을 억제하고 인 슐린 저항성을 유발한다고 보고되었다(38).

$\mathrm{C} 2 \mathrm{C} 12$ myoblast에서 유리 지방산에 의해 유발된 인슐린 저항성과 관련하여 $\mathrm{PTP} 1 \mathrm{~B}$ 의 유전자 발현에 대한 $\mathrm{MPH}$ 의 효과를 조사하기 위하여 분화 4 일차의 $\mathrm{C} 2 \mathrm{C} 12$ myoblast에 $1 \mathrm{mM}$ 의 $\mathrm{PA}$ 와 $100 \mathrm{nM}$ 의 insulin, $\mathrm{MPH}$ 를 농도별 $(10,100$, $1,000 \mu \mathrm{g} / \mathrm{mL}$ )로 처리한 후, RT-PCR을 통해 PTP1B의 mRNA 발현량 변화를 비교하였다. 무처리군인 대조군에 비해 인슐린 처리군에서는 PTP1B 유전자 발현량이 약 $61 \%$ 감소하였고, 이로서 인슐린 신호전달기작이 활성화 됨을 확인할 수 있었다. PA처리 후 인슐린 처리군에서는 PTP1B 유전자 발현량이 약 $87 \%$ 로 증가하였다. 추가적으로 $\mathrm{MPH}$ 을 처리한 경우, 유의적 차이는 확보되지 않았지만 각 농도 에서 $83 \%, 75 \%, 77 \%$ 수준으로 PTP1B 유전자 발현량을 다소 감소시키는 것을 확인할 수 있었다(Fig. 5). 
고지방식이나, 고혈당 등에 의해 유도된 인슐린저항성은 주로 PTP1B의 발현의 증가와 관련이 되어 있는 것으로 보고되고 있으며(39-41), PTP1B 발현의 저해로 근육세포에 서 PA로 유도된 인슐린 저항성을 개선시켰다는 보고도 있 다(42) Nieto-Vasquez 등에 의하면, immortalized PTP1B deficient myocytes에서 인슐린 관련 포도당 유입이 증가됨 을 보고한 바 있으며(43), Delibegovic 등은 muscle-specific PTP1B deletion mice에서 고지방식이 후에 포도당 유입 및 인슐린 신호전달이 개선되었다고 보고하였다(44).

본 연구 결과에서는 PTP1B mRNA의 발현량이 확연한 차이로 감소되지는 않았다. 그러나 인슐린 신호전달과정의 최종단계에서 $\mathrm{MPH}$ 에 의해 포도당 흡수량이 크게 증가하 였고, PTP1B 저해활성도 매우 높았다는 결과를 근거로 $\mathrm{MHP}$ 는 아마도 유전자 수준에서의 발현억제보다도 PTP1B

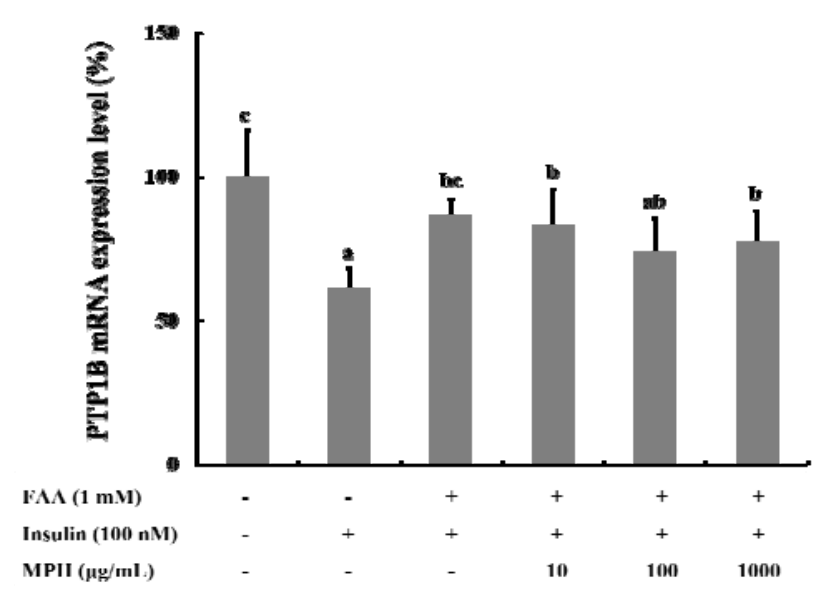

Fig. 5. Effects of melania snail hydrolysates treated with protamex (MPH) on the PTP1B mRNA expression in $\mathrm{C2C12}$ myoblast.

The mRNA expression levels of PTP1B were measured by RT-PCR and calculated with the ratio of PTP1B/B-actin. Data are representative of three independent experiments as mean \pm SE. a, b, and $c$ mean they are significantly different groups at $p=0.05$.
가 단백질로 합성된 후 효소 활성을 저해하는 기작으로 작용하였을 것으로 사료된다.

\section{췌장 베타세포에서 고농도 당독성에 대한 보호 효과}

포도당은 인체에서 일차적인 에너지원이자, 췌장 베타세 포의 주요 조절자이기도 하다. 췌장의 베타세포의 주요기 능은 혈액의 포도당 농도가 증가하면 인슐린을 분비하여 혈당을 정상범위로 유지하는 데 있다. 그러나 고농도 혈당 에 장기간 노출되게 되면 췌장 베타세포는 혈당조절의 장애 가 발생하고 결국 파괴된다. 이를 당독성(glucose toxicity) 이라고 하며, 인슐린 유전자 발현의 감소 및 인슐린 합성이 저해되어 궁극적으로 제 2형 당뇨의 주요한 2차적 병인이 되고 있다(45).

고농도의 당독성에서 췌장의 베타세포에 대한 $\mathrm{MPH}$ 의 보호 효과를 확인하기 위해 췌장 베타세포인 INS-1세포를 이용하여 고농도 포도당에서의 MPH에 의한 인슐린 mRNA 의 발현량을 비교하였다. 우선 고농도의 포도당에 장시간 노출될 때, 당독성이 유발되는 최적 노출시간을 결정하기 위해, 정상 포도당(control glucose(CG): $11.1 \mathrm{mM}$ ), 고농도 포도당(high glucose(HG): $30 \mathrm{mM}$ )배지에서 24, 48, 72, 96시 간별로 배양한 후 세포 생존률과 인슐린의 mRNA 발현량을 확인하였다. CG에서는 시간이 지남에 따라 INS-1 세포의 생존율 및 인슐린 mRNA의 발현량은 변화가 없었다. 그러 나 $\mathrm{HG}$ 에서는 고농도 포도당 노출시간이 증가함에 따라 세포 생존율은 감소하여, 96시간 후 약 $75 \%$ 로 감소되었다 (Fig. 6A). 또한 인슐린 mRNA 발현량도 고농도 포도당 노출 시간 48 시간 후 약 $80 \%$ 로 감소하였고, 96시간 후 약 $67 \%$ 로 최저값을 나타내었다(Fig. 6B). 따라서 96시간 고농도 포도 당 처리에 의해 당독성이 유도됨을 확인할 수 있었다.

96시간의 장기간 고농도 포도당 독성이 유도된 환경에서 다슬기 가수분해물 $\mathrm{MPH}$ 에 의한 췌장 베타세포의 보호효
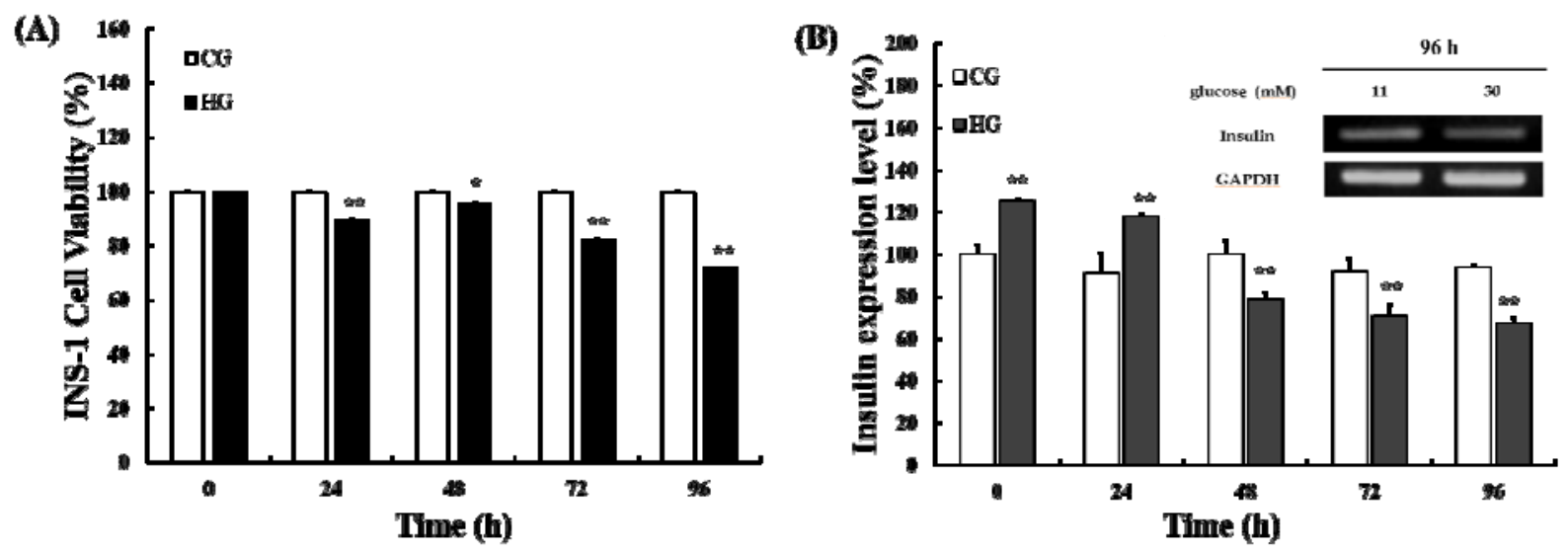

Fig. 6. Effects of the high glucose concentration on the INS-1 cell viability (A) and on insulin mRNA expression (B).

The mRNA level of insulin was determined by RT-PCR and calculated with the ratio of insulin/GAPDH. Data are representative of three independent experiments as mean \pm SE $(*, p<0.05 ; * *, p<0.01)$. 
과를 확인하기 위하여, $\mathrm{HG}$ 에서 72시간 동안 배양한 INS-1 세포에 $\mathrm{MPH}$ 를 농도별 $(1,10,100,1,000 \mathrm{\mu g} / \mathrm{mL})$ 로 24시간 처리하여 총 96시간 배양하여, 세포생존율과 인슐린 mRNA 발현량을 비교하였다. 고농도 당독성이 유도된 $\mathrm{HG}$ 에서 $\mathrm{MPH}$ 처리 농도가 증가함에 따라 세포 생존율은 $100 \%$ 가까이 회복됨을 확인할 수 있었으며, $1,000 \mathrm{\mu g} / \mathrm{mL}$ 농도에 서는 약 $200 \%$ 생존율을 보여 세포 증식인자로서의 작용을 나타냄을 알 수 있었다(Fig. 7A). 또한 인슐린 mRNA 발현량 에 있어서는 1-100 $\mu \mathrm{g} / \mathrm{mL}$ 농도 사이에서는 $92 \%, 125 \%$, $160 \%$ 증가하여 $\mathrm{MPH}$ 농도 의존적으로 인슐린 발현이 증가 함을 확인할 수 있었다(Fig. 7B). 따라서 고농도 포도당독성 하에서, 다슬기 가수분해물 $\mathrm{MPH}$ 는 췌장의 베타세포를 보 호하고, 인슐린 유전자 발현을 정상화시키는 것을 확인할 수 있었다.

이상의 결과에서 다슬기 가수분해물 MPH는 PTP1B 활 성을 저해함으로써 인슐린 신호전달 기작을 활성화하고, 인슐린 저항성 환경에서 포도당 흡수를 증진시켜 인슐린저 항성을 개선하였다. 또한 MPH는 고농도 포도당에 의해 유도되는 당독성 환경에서 췌장 베타세포를 보호하고 베타 세포에서 인슐린 mRNA 발현량을 정상화할 수 있다는 것을 확인할 수 있었다. 이러한 연구 결과는 다슬기 가수분해물 이 인슐린 저항성을 개선하면서 장기복용 시에 췌장의 베타 세포 보호기능을 가지는 항당뇨 소재로서 개발될 수 있는 기초적 자료가 될 것이다.

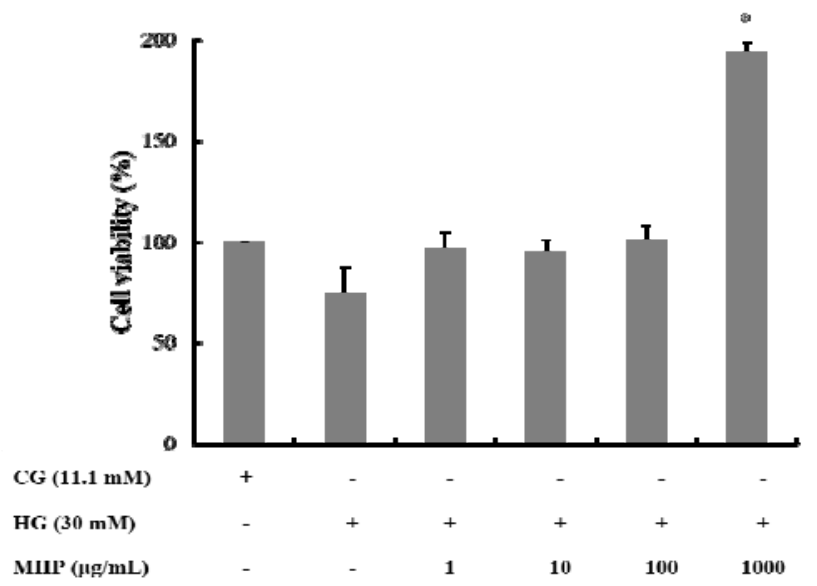

개선에 이용되어 왔으며, 특히 소변불통, 소갈증(당뇨) 등의 약용으로 이용되어 왔다. 본 연구에서는 이러한 다슬기를 대상으로 항당뇨에 대한 효능을 과학적으로 검증하고 그 기작을 규명하고자 하였다. 먼저 다슬기의 생물학적 기능 성을 높이기 위해 효소 가수분해를 실시하였으며, protamex 에 의한 가수분해도는 10 시간 후 약 $43 \%$ 수준을 나타내었 다. PTP1B는 인슐린 신호전달기전에서 IRS- 1 의 인산화를 방해하여 인슐린 민감성을 저해시키는 효소이다. protamex 를 이용한 다슬기 가수분해물(MPH)의 PTP1B에 대한 저해 활성은 $15.42 \pm 1.1 \mu \mathrm{g} / \mathrm{mL}$ 의 $\mathrm{IC}_{50}$ 값을 나타내어 양성대조군 ursolic acid의 $16.7 \mu \mathrm{g} / \mathrm{mL}$ 보다 높은 저해활성을 보이면서 강한 항당뇨 활성 소재로서의 가능성을 보였다. 이에 따라 유리지방산을 이용하여 $\mathrm{C} 2 \mathrm{C} 12$ myoblast에서 인슐린 저항 성을 유도하고, $\mathrm{MPH}$ 에 의한 포도당 흡수 정도를 확인하였 다. 그 결과, $1 \mathrm{mM} \mathrm{PA}$ 처리에 의해 약 $32 \%$ 수준으로 떨어진 포도당 흡수율은 MPH 처리에 의해 약 $199 \%$ 수준으로 증가 하였다. 또한 장기간 고농도의 포도당 $(30 \mathrm{mM})$ 에 의해 유도 된 당독성 조건에서 $\mathrm{MPH}$ 는 췌장의 베타세포 $\mathrm{INS}-1$ 세포의 생존율을 증가시키고, 대조군에 비해 약 $160 \%$ 인슐린 mRNA 발현량을 증가시켰다. 이러한 결과에서 $\mathrm{MPH}$ 는 PTP1B 활성을 저해함으로써 인슐린 신호전달 기작을 활성 화하고, 인슐린저항성 환경에서 포도당 흡수를 증진시켜 인슐린저항성을 개선하며, 나아가 고농도 포도당에 의해 유도되는 당독성환경에서 췌장 베타세포를 보호하고 인슐

Fig. 7. Effects of melania snail hydrolysates treated with protamex (MPH) on the INS-1 cell viability (A) and on the insulin mRNA expression level in glucotoxic conditions (B) INS-1 cell were treated with high glucose $(30 \mathrm{mM})$ for $72 \mathrm{~h}$ and then sample $(1-1,000 \mu \mathrm{g} / \mathrm{mL})$ for $24 \mathrm{~h}$.

The mRNA level of insulin was measured by RT-PCR and calculated with the ratio of insulin/GAPDH. Data are representative of three independent experiments as mean \pm SE. $\mathrm{a}, \mathrm{b}, \mathrm{c}, \mathrm{d}$ and * mean they are significantly different groups at $\mathrm{p}=0.05$.

\section{요 약}

다슬기는 예로부터 간염, 간경화, 지방간 등의 치료 및
린 mRNA발현량을 정상화할 수 있다는 것을 확인할 수 있었다. 


\section{References}

1. Jeong HJ, Lee SG, Lee EJ, Park WD, Kim JB, Kim HJ (2010) Antioxidant activity and anti-hyperglycemic activity of medicinal herbal extracts according to extraction methods. Korean J Food Sci Technol, 42, 571-577

2. Xu ML, Hu JH, Wang L, Kim HS, Jin CW, Cho DH (2010) Antioxidant and anti-diabetes activity of extracts from Machilus thunbergii S. et Z. Korean J Med Crop Sci, 18, 34-39

3. World Health Organization. Global report on diabetes. http://www.who.int/diabetes/global-report/en/ (accessed 2006).

4. Hwang JT, Kim SH (2012) Evaluation of anti-diabetic effect of biochanin A in $\mathrm{C} 2 \mathrm{C} 12$ myotube. Korean Soc Biotechnol Bioeng J, 27, 57-60

5. Yoo HJ (2012) Pharmacotherapy for postprandial hyperglycemia in Type 2 diabetes. J Korean Diabetes, 13, 39-43

6. Park KS, Ko SK, Chung SH (2003) Comparisons of antidiabetic effect between ginseng radix alba, ginseng radix rubra and panax quinquefoli radix in MLD STZ-induced diabetic Rats. J Ginseng Res, 27, 56-61

7. Lee JM (2014) Antihyperglycemic agent combination therapy for patients with type 2 diabets mellitus. J Korean Med Assoc, 57, 435-443

8. Kwon EJ, Hong SG, Kim MM, Kim JW, Kim DW, Chung KT (2014) Effects of ginseng berry water extract on the polysaccharide hydrolysis of extracellular enzymes and intracellular PTP1B and AKT1. J Life Sci, 24, 1006-1011

9. Im SA, Kim KH, Shin EJ, Do SG, Jo TH, Park YI, Lee CK (2013) Effects of antidiabetic agent, aloe QDM complex, on intracellular glucose uptake. Korean $\mathrm{J}$ Pharmacogn, 44, 75-82

10. Cho EK, Choi YJ (2013) Antioxidant, antidiabetic and anti-inflammatory effects of extracts and fractions from Parthenocissus tricuspidata stems. J Life Sci, 23, 399-405

11. Kang TS, Kang MS, Sung JM, Kang AS, Shon HR, Lee SY (2001) Effects of Pleurotus eryngii on the blood glucose and cholesterol in diabetic rats. Korean J Mycol, 29, 86-90

12. Kim YH, Lee TK, Cha YS (1985) Studies on the Nutritive Component of black snail (Semisulcospira libertina). Bull Agric College Chonbuk Univ, 16, 101-105

13. Kim YK, Moon HS, Lee MH, Park MJ, Lim CW, Park HY, Park JI, Yoon HD, Kim DH (2009) Biological
Activities of seven melania snails in Korea. Korean $\mathbf{J}$ Fish Aquat Sci, 42, 434-441

14. Lee MS, Park JB, Yoon SH (2005) Hepatoprotective effects of the water extract from Semisulcospira gottschei against liver injuries induced by carbon tetrachloride in rats. J Korean Soc Hyg Sci, 11, 17-26

15. Park YM, Lim JH (2015) Protective effect of Semisulcospira libertina extract on induced hepatitis in rats. J Life Sci, 25, 539-547

16. Lim CW, Kim YK, Kim DH, Park JI, Lee MH, Park HY, Jang MS (2009) Comparison of quality characteristics of melania snails in Korea. Korean J Fish Aquat Sci, 42, 555-560

17. Lee MH, Kim YK, Moon HS, Kim YA, Yoon NY, Lim CW, Park HY, Kim DH (2010) Antioxidant activities of five melania snails of the genus Semisulcospira in Korea. Korean J Fish Aquat Sci, 43, 188-194

18. Choi JS, Kim JW, Park JB, Pyo SE, Hong YK, Ku SK, Kim MR (2017) Blood glycemia-modulating effects of melanian snail protein hydrolysates in mice with type II diabetes. Int J Mol Med, 39, 1437-1451

19. AOAC (1995) Official Methods of Analysis $16^{\text {th }} \mathrm{ed}$, Association of Official Analytical Chemists, Washington DC, USA, p 69-74

20. Scopes RK (1987) Protein Purification: Principles and Practice. $2^{\text {nd }}$ ed, Springer-Verlag, New York, NY, USA, p 279-280

21. Shim TH, Han KS, Lee TJ, Cheong EH, Lee HK (1994) Comparison of lipid and amino acid in Semisulcospira gorrschei tissue. J Food Hyg Saf, 9, 81-87

22. Shin MJ, Park MJ, Youn MS, Lee YS, Nam MS, Park IS, Jeong YH (2006) Effects of silk protein hydrolysates on blood glucose and serum lipid in $\mathrm{db} / \mathrm{db}$ diabetic mice. J Korean Soc Food Sci Nutr, 35, 1343-1348

23. Jang SY, Gu YA, Park NY, Kim IS, Jeong YJ (2007) Physicochemical property changes of whole soymilk dependent on hydrolysis conditions. Korean J Food Preserv, 14, 394-399

24. Yoon SJ (2013) Diabete and therapeutic agents for glycemic control in diabetes mellitus, Report of Korea Drug Development Fund http://kddf.org/bbs/bbs.asp? mode $=$ view $\&$ IDX $=785 \& p=9 \&$ cateId $=39$

25. Koren S, Fantus IG (2007) Inhibition of the protein tyrosine phosphatase PTP1B: potential therapy for obesity, insulin resistance and type-2 diabetes mellitus. Best Pract Res Clin Endocrinol Metab, 21, 621-640

26. Kulkarni RN, Bruning JC, Winnay JN, Postic C, 
Magnuson MA, Kahn CR (1999) Tissue-specific knockout of the insulin receptor in pancreatic $\beta$ cells creates an insulin secretory defect similar to that in type 2 diabetes. Cell, 96, 329-339

27. Lee J, Pilch P (1994) The insulin receptor: structure, function, and signaling. Am J Physiol, 266, C319-C334

28. Saltiel AR, Kahn CR (2001) Insulin signalling and the regulation of glucose and lipid metabolism. Nature, 414, 799-806

29. Kim SM, Lee YM, Kim MJ, Nam SY, Kim SH, Jang HH (2013) Effects of Agrimonia pilosa Ledeb. water extract on a-glucosidase inhibition and glucose uptake in $\mathrm{C} 2 \mathrm{C} 12$ skeletal muscle cells. Korean J Food Nutr, 26, 806-813

30. Yip SC, Saha S, Chernoff J (2010) PTP1B: a double agent in metabolism and oncogenesis. Trends Biochem Sci, 35, 442-449

31. Panzhinskiy E, Ren J, Nair S (2013) Pharmacological inhibition of protein tyrosine phosphatase 1B: a promising strategy for the treatment of obesity and type 2 diabetes mellitus. Curr Med Chem, 20, 2609-2625

32. van Huijsduijnen RH, Sauer WHB, Bombrun A, Swinnen D (2004) Prospects for inhibitors of protein tyrosine phosphatase 1B as antidiabetic drugs. J Med Chem, 247, 4142-4146

33. Elchebly M, Payette P, Michaliszyn E, Cromlish W, Collins S, Loy AL, Normandin D, Cheng A, Himms-Hagen J, Chan CC, Ramachandran C, Gresser MJ, Tremblay ML, Kennedy BP (1999) Increased insulin sensitivity and obesity resistance in mice lacking the protein tyrosine phosphatase-1B gene. Sci, 283, 1544-1548

34. Malamas MS, Sredy J, Gunawan I, Mihan B, Sawicki DR, Seestaller L, Sullivan D, Flam DR (2000) New azolidinediones as inhibitors of protein tyrosine phosphatase 1B with antihyperglycemic properties. J Med Chem, 43, 995-1010

35. Choi CS (2009) Pathogenesis of insulin resistance. Korean J Med, 77, 171-177

36. Winer DA, Luck H, Tsai S, Winer S (2016) The intestinal immune system in obesity and insulin resistance. Cell Metab, 23, 413-426
37. Boden G (2011) Obesity, insulin resistance and free fatty acids. Curr Opin Endocrinol Diabetes Obes, 18, 139-143

38. Li HB, Yang YRY, Mo ZJ, Ding Y, Jiang WJ (2015) Silibinin improves palmitate-induced insulin resistance in $\mathrm{C} 2 \mathrm{C} 12$ myotubes by attenuating IRS-1/PI3K/Akt pathway inhibition. Braz J Med Biol Res, 48, 440-446

39. Pauli JR, Ropelle ER, Cintra DE, De Souza CT, da Silva AS, Moraes JC, Prada PO, de Almeida Leme JA, Luciano E, Velloso LA, Carvalheira JB, Saad MJ (2010) Acute exercise reverses aged-induced impairments in insulin signaling in rodent skeletal muscle. Mech Ageing Dev, 131, 323-329

40. Gonzalez-Rodriguez A, Gutierrez JAM, Sanz-Gonzalez S, Ros M, Burks DJ, Valverde AM (2010) Inhibition of PTP1B restores IRS1-mediated hepatic insulin signaling in IRS2-deficient mice. Diabetes, 59, 588-599

41. Zabolotny JM, Kim YB, Welsh LA, Kershaw EE, Neel BG, Kahn BB (2008) Protein-tyrosine phosphatase 1B expression is induced by inflammation in vivo. $\mathrm{J}$ Biol Chem, 283, 14230-14241

42. Zhao M, Zhang ZF, Ding Y, Wang JB, Li Y (2012) Astragalus polysaccharide improves palmitate-induced insulin resistance by inhibiting PTP1B and NF-kappaB in C2C12 myotubes. Molecules, 17, 7083-7092

43. Nieto-Vazquez I, Fernandez-Veledo S, de Alvaro C, Rondinone CM, Valverde AM, Lorenzo M (2007) Protein-tyrosine phosphatase 1B-deficient myocytes show increased insulin sensitivity and protection against tumor necrosis factor-a-induced insulin resistance. Diabetes, 56, 404-413

44. Delibegovic M, Bence KK, Mody N, Hong EG, Ko HJ, Kim JK, Kahn BB, Neel BG (2007) Improved glucose homeostasis in mice with muscle-specific deletion of protein-tyrosine phosphatase 1B. Mol Cell Biol, 27, 7727-7734

45. Unger RH, Grundy S (1985) Hyperglycaemia as an inducer as well as a consequence of impaired islet cell function and insulin resistance: implications for the management of diabetes. Diabetologia, 28, 119-121 